\title{
Aplikasi Pengusulan dan Pemantauan Pelaksanaan Penelitian Pengabdian Masyarakat Universitas Ibrahimy
}

\section{Application for Proposing and Monitoring of the Research and Community Service Activity at Ibrahimy University}

\author{
Ahmad Homaidi \\ Universitas Ibrahimy, Indonesia
}

\section{Article Info}

\section{Article history:}

Received, 20 Oktober 2020

Revised, 2 Mei 2021

Accepted, 10 Mei 2021

\section{Kata Kunci:}

Aplikasi

Penelitian

Pengabdian Masyarakat

Universitas Ibrahimy

Waterfall

\section{Keywords:}

\section{Application}

Research

Community Service

Ibrahimy University

Waterfall

\begin{abstract}
ABSTRAK
Proses pengusulan dan pelaksanaan penelitian dan pengabdian masyarakat di Universitas Ibrahimy yang masih menggunakan model konvensional. Bahkan, sulit ditemukan dokumentasi pelaksanaan serta hasil penelitian dan pengabdian kepada masyarakat yang dilakukan. Berdasarkan hal tersebut, dilakukan penelitian dengan judul aplikasi pengusulan dan pemantauan pelaksanaan penelitian dan pengabdian masyarakat Universitas Ibrahimy. Penelitian ini menggunakan metode waterfall, sebagai salah satu metode dalam pengembangan sistem. Proses penerapan metode ini menerapkan kaidah-kaidah System Development Life Cycle. Penerapan metode ini dilakukan secara sistematis mulai dari tahap communication, planning, modelling, construction dan deployment, sehingga aplikasi yang dihasilkan sesuai dengan kebutuhan pengguna. Hasil yang didapatkan dari penelitian ini, penelitian dan pengabdian kepada masyarakat dapat terorganisir dengan baik, karena proses pengusulan dan penilaian dapat dilakukan melalui sistem, serta seluruh data dapat terdata dengan baik dan segala berkas yang dibutuhkan sudah tersedia di aplikasi. Namun masih diperlukan perbaikan standar operasional prosedur dalam beberapa proses bisnis yang dilakukan, sehingga seluruh proses bisnis dapat dilakukan menggunakan aplikasi yang online, sehingga dapat menjadi lebih efektif dan efisien.
\end{abstract}

\section{ABSTRACT}

The process of proposal, research and community service at Ibrahimy University uses conventional models as yet. Even the documentation of implementation, results of research and community service that has been completed is difficult to find. Based on this, a research was carried out with the application title "proposing and monitoring the implementation of research and community service at Ibrahimy University". This study uses the waterfall method, as one of the methods in system development. The process of applying this method applies the principles of the System Development Life Cycle. The application of this method is carried out systematically starting from the stage of communication, planning, modeling, construction and deployment, so that the resulting application is in accordance with user needs. The results obtained from this research, research and community service can be well organized, because the process of proposal and assessment can be done through the system, and all data can be recorded properly and all required files are available in the application. However, it is still necessary to improve standard operating procedures in several business processes, so that all business processes can be carried out using online applications, so that they can be more effective and efficient.

This is an open access article under the CC BY-SAlicense.

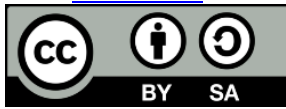

\section{Penulis Korespondensi:}

Ahmad Homaidi,

Program Studi Teknologi Informasi,

Universitas Ibrahimy, Indonesia

Email: ahmadhomaidi@ibrahimy.ac.id 


\section{PENDAHULUAN}

Universitas Ibrahimy Situbondo adalah salah satu perguruan tinggi yang berada di Situbondo yang berada di bawah naungan Pondok Pesantren Salafiyah Syafi'iyah Sukorejo Situbondo. Perguruan tinggi ini terbilang perguruan tinggi yang baru tapi lama, hal ini dikarenakan Universitas Ibrahimy ini merupakan gabungan dari beberapa perguruan tinggi yang ada di bawah naungan Pondok Pesantren Salafiyah Syafi'iyah Sukorejo Situbondo, yaitu: Institut Agama Islam Ibrahimy Sukorejo, AMIK Ibrahimy Situbondo, Akademi Perikanan Ibrahimy dan Akademi Kebidanan Ibrahimy.

Universitas Ibrahimy sebagai perguruan tinggi profesional mempunyai fungsi untuk menjalankan Tri Dharma Perguruan Tinggi, yaitu Pendidikan dan Pengajaran, Penelitian dan Pengabdian Masyarakat [1][2]. dalam melaksanakan pendidikan dan pengajaran dikomandani oleh bagian akademik, sedangkan untuk penelitian dan pengabdian kepada masyarakat dikomandani oleh Lembaga Penelitian dan Pengabdian Kepada Masyarakat (LP2M) Universitas Ibrahimy.

LP2M Universitas Ibrahimy memiliki tanggung jawab untuk memantau dan menggerakkan dosen dalam melakukan Penelitian dan Pengabdian kepada masyarakat. Dalam melaksanakan kegiatan penelitian dan pengabdian ini pihak LP2M masih menggunakan model konvensional untuk membuat pengumuman, penerimaan proposal serta laporan akhir dari penelitian dan pengabdian masyarakat, atau bahkan luaran yang dihasilkan tidak terdokumentasi dengan baik dan bahkan terdapat pelaksanaan penelitian dan pengabdian masyarakat yang tidak menghasilkan luaran publikasi. Hal ini terjadi karena sumber daya manusia yang kurang memahami proses pelaksanaan penelitian dan pengabdian yang baik dan juga ruang tempat untuk melakukan pengarsipan yang terbatas. Sehingga arsip-arsip proposal serta laporan dari penelitian dan pengabdian sulit untuk ditemukan, belum lagi arsip yang rusak karena disebabkan oleh lamanya waktu penyimpanan dan penyebab lainnya.

Untuk membuat proses administrasi pengelolaan pengajuan proposal penelitian dan pengabdian masyarakat yang lebih baik, maka dibutuhkan sebuah aplikasi yang dapat menangani masalah tersebut. Dengan demikian dapat mempermudah pihak LP2M dalam melakukan dokumentasi serta mendistribusikan kepada tim reviewer untuk melakukan penilaian terhadap proposal yang diajukan. Begitu juga terkait laporan penelitian dan pengabdian kepada masyarakat yang dilakukan oleh dosen, dapat disajikan dengan baik, mudah dan cepat saat dibutuhkan oleh pimpinan maupun pihak eksternal.

Saat ini penggunaan database online sudah menjadi trend bahkan hampir seluruh aktivitas manusia memanfaatkan database. Penelitian yang dilakukan oleh Mestika Dewi tentang penggunaan database online Science Direct, dapat ditarik kesimpulan bahwa tingkat keterpakaian sumber informasi dalam format digital mempengaruhi terhadap pengambilan kebijakan untuk pengadaan koleksi pustaka elektronik [3]. Hal ini dikarenakan sistem database online sudah menjadi alternatif dalam menyediakan informasi [4][5], sehingga kebutuhan informasi dapat dilayani dengan cepat dan tepat. Selain itu, dengan penggunaan database, dapat memudahkan dalam mengelola dan mengorganisir data-data penelitian dan pengabdian sehingga dapat disajikan dalam berbagai bentuk yang dibutuhkan [6]. Oleh karena itu, diperlukan aplikasi yang dapat digunakan oleh pihak LP2M Universitas Ibrahimy untuk melakukan pemantauan pelaksanaan dan pelaporan penelitian dan pengabdian masyarakat, serta dapat dengan mudah diakses oleh pengguna dan dapat menerapkan standar proses penelitian dan pengabdian yang lebih efektif dan efisien.

\section{METODE PENELITIAN}

Dalam membangun sistem penerimaan proposal penelitian dan pengabdian kepada masyarakat ini diperlukan tahapantahapan sistematis, sehingga sistem yang dihasilkan dapat memberikan kemudahan atau menghasilkan keuntungan.[7] Untuk menjamin kualitas penelitian yang dilakukan, dalam penelitian ini menggunakan metode klasik dalam System Development Life Cycle yaitu metode waterfall [8]. Metode ini digunakan untuk memastikan setiap tahapan dilakukan secara teratur dan dilaksanakan dengan baik [9][10].

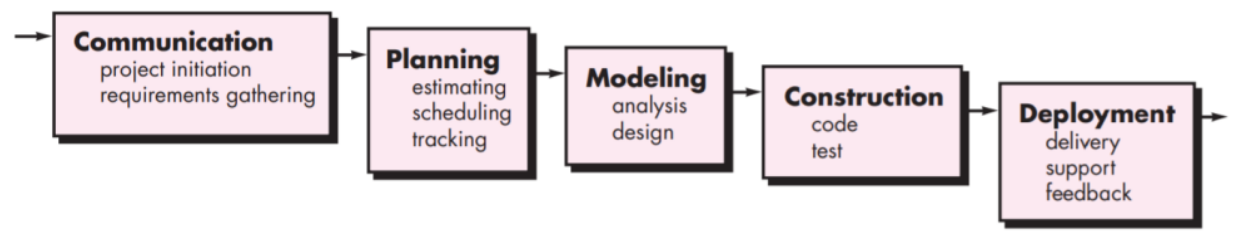

Gambar 1. Metode Waterfall [10]

Communication Tahapan ini dilakukan untuk menjalin komunikasi dengan pihak LP2M Universitas Ibrahimy untuk menyampaikan maksud dan tujuan dari penelitian yang dilakukan. Sehingga dari komunikasi yang dibangun dengan baik tersebut dapat didapatkan gambaran terkait problem statement yang dihadapi, serta juga menggali informasi dan keinginan pihak LP2M terkait sistem yang akan dibangun. Planning Setelah komunikasi dengan pihak LP2M selesai dilakukan dan menemukan kepastian terkait permasalahan yang dihadapi serta solusi yang diinginkan, selanjutnya adalah melakukan perencanaan yang berkaitan dengan tugas teknis yang akan dilakukan, resiko yang mungkin terjadi, sumber daya yang dibutuhkan, produk yang ingin dihasilkan, jadwal kerja yang akan dilaksanakan, serta tracking proses pengerjaan. Modelling Yang dilakukan pada tahap ini adalah melakukan perancangan dan pemodelan sistem yang difokuskan kepada perancangan struktur data, arsitektur software, interface, serta algoritma yang akan digunakan dalam program. Tujuan utamanya adalah untuk memberikan gambaran secara garis besar dari apa yang dikerjakan. Construction Tahapan ini adalah tahap penerjemahan hasil analisis dan desain yang 
dilakukan pada tahap modelling ke dalam bahasa pemrograman yang dipilih, sehingga menjadi sebuaha aplikasi yang diharapkan menjadi solusi dari permasalahan yang dihadapi. Setelah proses pengkodean telah selesai dilakukan, kemudian dilanjutkan dengan melakukan uji coba terhadap aplikasi yang telah dibuat. Sehingga dapat diketahui letak kesalahan-kesalahan yang mungkin terjadi saat melakukan pengkodean. Kemudian dari kesalahan yang ditemukan tersebut dilakukan perbaikan-perbaikan. Deployment Tahapan ini merupakan tahapan terakhir, yaitu penerapan aplikasi untuk dapat digunakan secara langsung oleh pihak-pihak yang berkaitan dengan proses pengajuan proposal penelitian dan pengabdian kepada masyarakat, yaitu para dosen di lingkungan Universitas Ibrahimy dan LP2M sebagai leading sector dalam pelaksanaan dharma penelitian dan pengabdian kepada masyarakat.

\section{HASIL DAN ANALISIS}

Berdasarkan hasil requirement yang dilakukan pada saat penelitian, proses pengajuan pelaksanaan penelitian dan pengabdian kepada masyarakat $(\mathrm{PkM})$ yang berjalan di Universitas Ibrahimy masih belum berjalan dengan efektif serta administrasi yang berkaitan dengan penelitian tersebut bisa dikatakan belum terorganisir dengan baik. Dari hasil analisa yang dilakukan didapatkan beberapa proses bisnis yang dilakukan dalam pelaksanaan penelitian dan PkM yang dilaksanakan oleh Universitas Ibrahimy, mulai dari proses penerimaan pengajuan proposal sampai pada pelaksanaan seminar hasil. Setelah menggali lebih dalam terkait proses bisnis yang berjalan, selanjutnya dapat diketaui kebutuhan fungsional yang harus tercover dalam aplikasi yang akan dibangun. Berikut ini adalah gambaran hasil analisa dan pemodelan yang dilakukan dalam penelitian:

\subsection{Use Case Diagram}

Use case diagram merupakan salah satu diagram unified modelling language (UML) yang digunakan untuk menggambarkan perilaku aktor yang terlibat dalam sistem serta kaitannya dengan objek [11][12]. Use case diagram yang dibuat dalam perancangan penelitian ini terdapat 3 aktor yang berkaitan erat dengan sistem, yaitu Administrator yang dalam hal ini adalah pihak LP2M, Dosen, dan Reviewer yang merupakan inheritance dari dosen yang bertugas memberikan penilaian terhadap proposal yang diajukan oleh dosen.

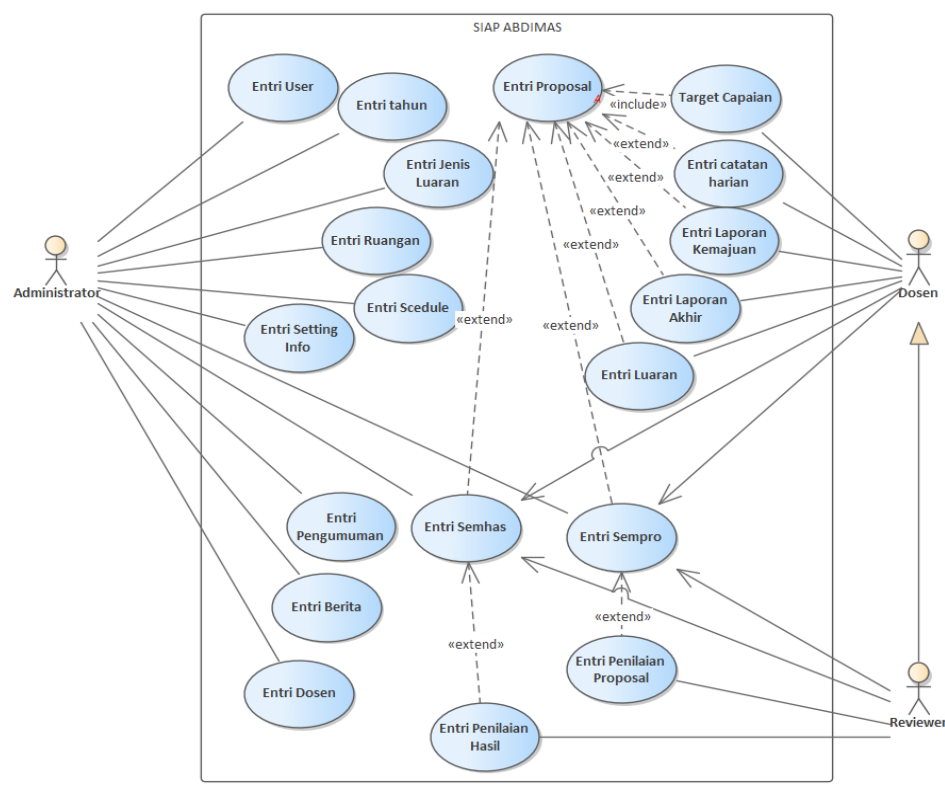

Gambar 2. Use Case Diagram

Berdasarakan gambar 2, dapat diketahui peranan setiap aktor. Peran utama yang dilakukan oleh Administrator adalah membuat periode penerimaan proposal, melakukan penjadwalan dan melakukan kontrol terhadap pelaksanaan. Kemudian untuk dosen adalah sebagai pengusul proposal yang diberikan akses untuk submit proposal, membuat catatan harian, laporan kemajuan, laporan akhir dan mengakses jadwal. Sementara untuk Reviewer dapat mengakses jadwal, serta memberikan penilaian terhadap proposal dan hasil pelaksanaan yang telah dilakukan.

\subsection{Activity Diagram}

Activity diagram dibuat untuk menggambarkan proses yang dilakukan oleh aktor, sehingga proses yang dijalankan dapat diketahui berawal dari mana dan berakhir dimana [13]. Gambar 3 merupakan Activity diagram dari penelitian ini. 


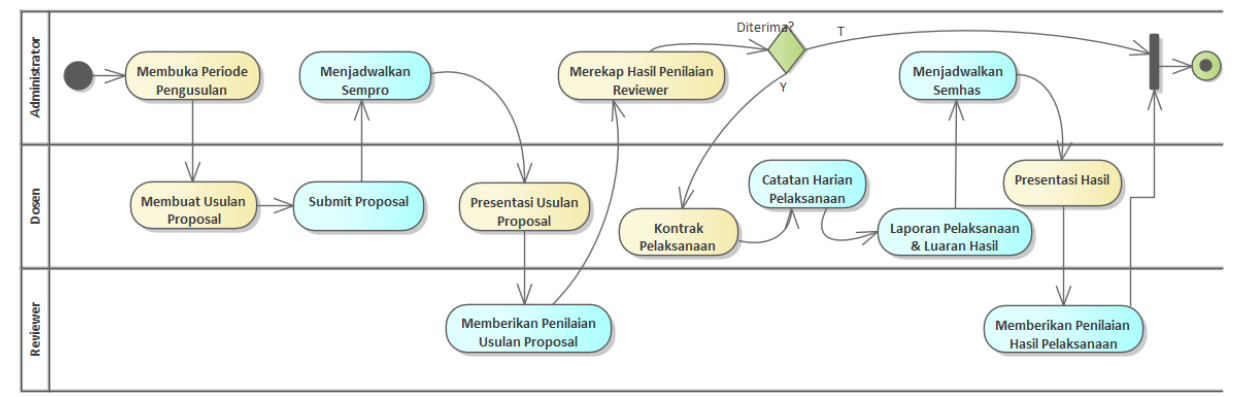

Gambar 3. Acitivity Diagram

Gambar 3 menggambarkan proses bisnis dimulai dari Administrator yang membuka periode pengusulan, kemudian dosen membuat proposal usulan dan mensubmit ke website LP2M. Berdasarkan proposal-proposal yang telah disubmit oleh dosendosen, pihak administrator kemudian menjadwalkan pelaksanaan seminar proposal, yang di dalam seminar proposal tersebut dosen pengusul diharuskan untuk mempresentasikan proposalnya dan nantinya akan diberikan penilaian oleh reviewer. Berdasarkan hasil penilaian reviewer tersebut kemudian pihak administrator melakukan perangkingan proposal berdasarkan hasil penilaian dari reviewer, dan menentukan proposal-proposal mana yang layak untuk didanai. Setelah ditentukan proposal mana yang didanai, kemudian dilanjutkan dengan penandatangan kontrak pelaksanaan. Berdasarkan kontrak yan gdibuat tersebut barulah pengusul dapat melaksanakan usulannya, dialnjutkan dengan memasukkan catatan harian, serta melaporkan hasil pelaksanaannya. Terakhir setelah masa pelaporan akhir, pihak administrator kemudian menjadwalkan untuk seminar hasil, sebagai presentasi akhir dari dosen pengusul terkait pelaksanaan usulannya, dan tidak lupa disini reviewer juga memberikan penilaian sebagai masukan dan evaluasi terhadap pelaksanaan penelitian/PkM dari dosen.

\subsection{Class Diagram}

Class diagram merupakan diagram UML yang digunakan untuk menggambarkan kelas-kelas, atribut serta operasi apa yang dilakukan dalma kelas tersebut [14]. Pada gambar 4 adalah Class Diagram dari sistem yang dibangun.

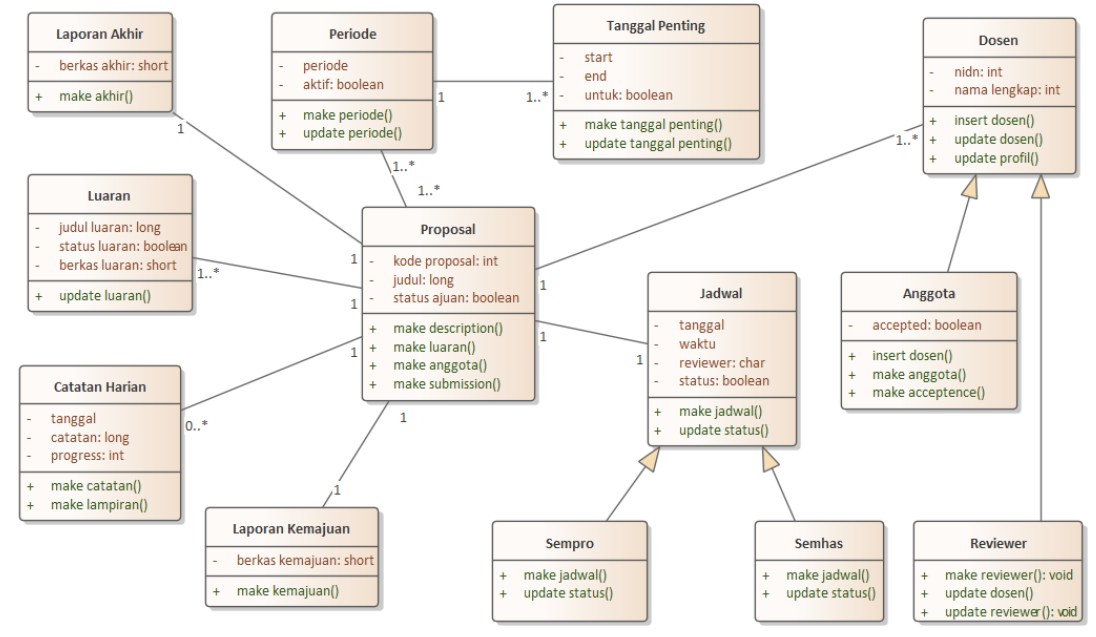

Gambar 4. Class Diagram

Class diagram sebagaimana gambar 4 dapat diketahui asosiasi dari kelas-kelas yang dibuat, begitu juga generalization dan inheritance dari kelas-kelas yang dibuat terkait perancangan sistem ini.

\subsection{Construction}

Setelah analisa dan pemodelan sistem selesai dilakukan, selanjutnya adalah kontruksi dari hasil analisa dan pemodelan yang telah dibuat. Kontruksi yang dibangun dalam sistem ini adalah menggunakan bahasa pemrograman PHP, dengan tujuan agar aplikasi yang dibangun dapat dionlinekan dan dapat diakses darimanapun. Kontruksi dari aplikasi yang dibangun dapat digambarkan sebagaimana tampilan-tampilan pada gambar 5 sampai gambar 18 . 


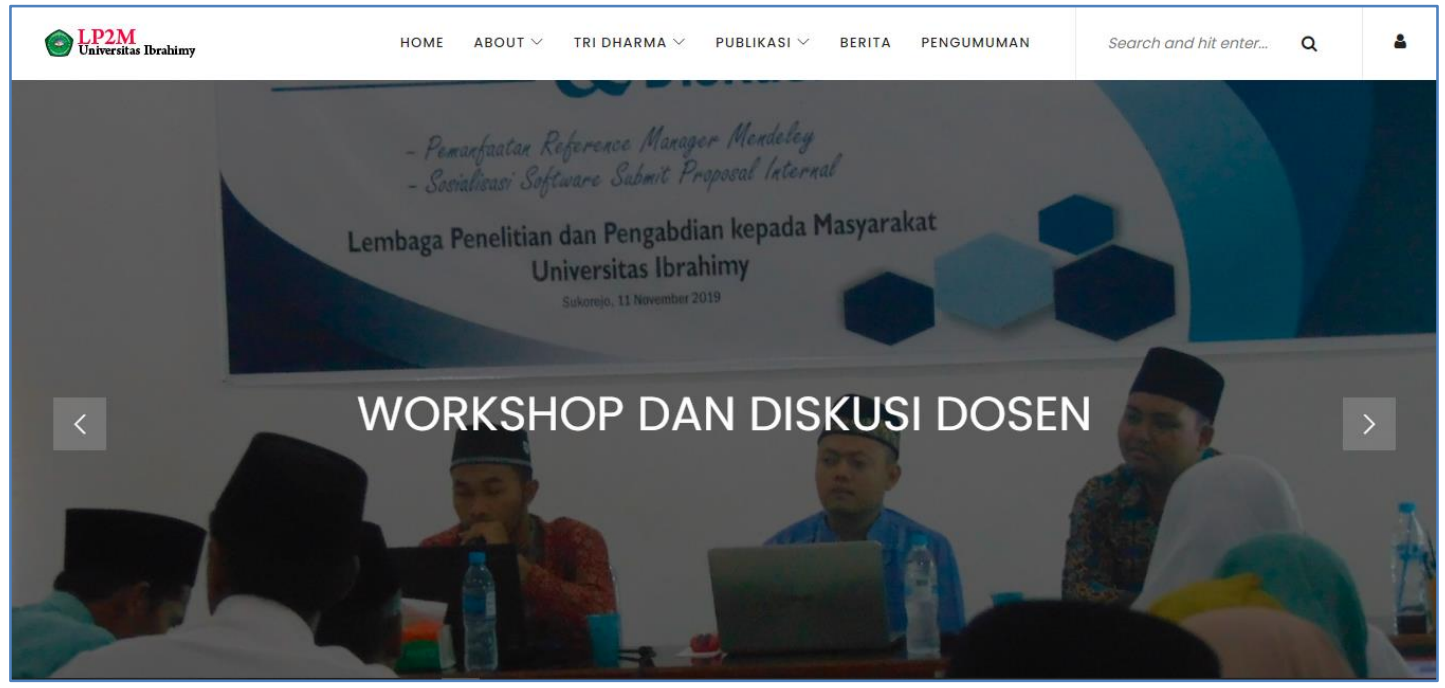

Gambar 5. Dashboard Tampilan Utama Website

Untuk melakukan pengusulan proposal, dosen diharuskan untuk login terlebih dahulu melalui icon user yang terdapat di navigation menu di bagian kanan atas. Setelah itu akan diarahkan ke tampilan dosen berikut menu-menu yang dapat diakses oleh dosen. Setelah itu jika profil dosen belum lengkap maka akan diarahkan menuju halaman profil atau dapat diakses melalui menu yang telah disediakan. Gambar 6 adalah tampilan untuk halaman dosen.

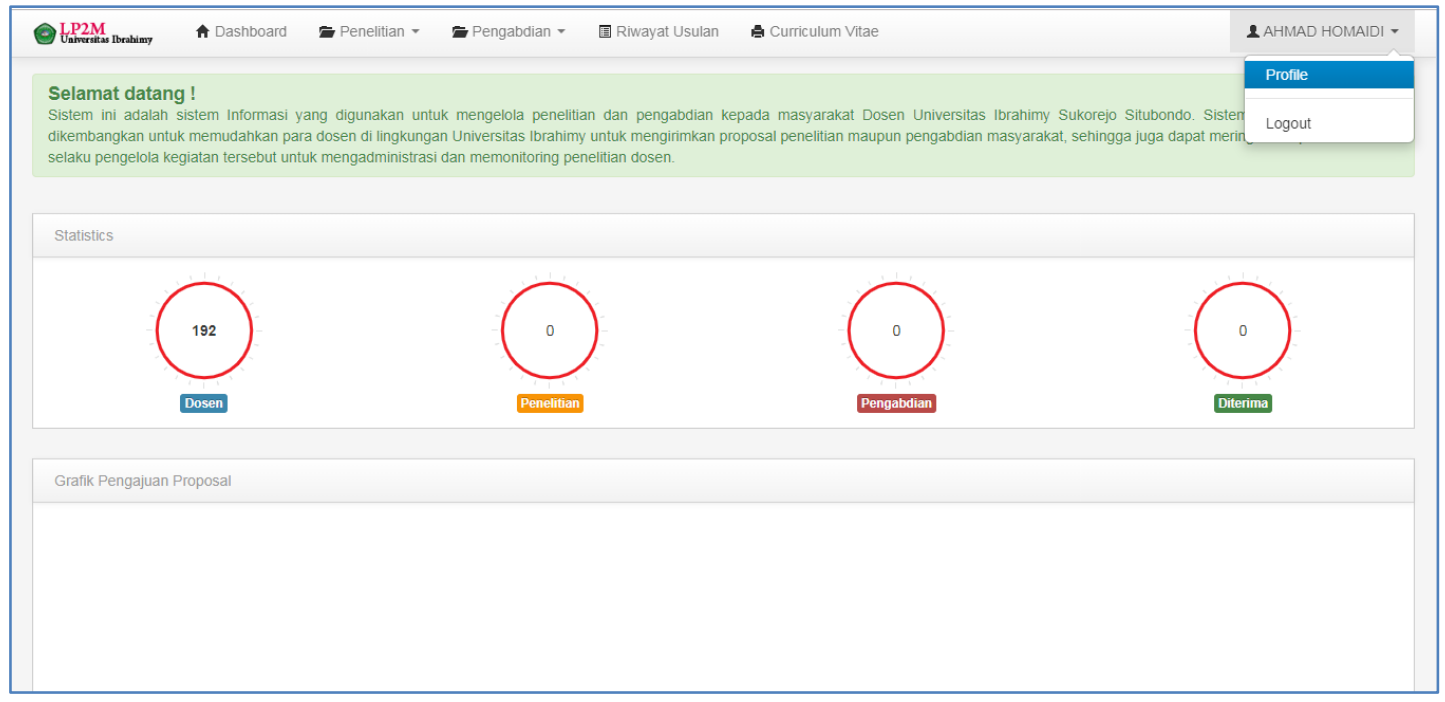

Gambar 6. Tampilan Halaman Dosen

Setelah mengklik menu profil maka diarahkan ke form untuk update data profil yang di dalamnya memuat data lengkap dosen. Pada form sebagaimana gambar 7 memuat identitas dosen meliputi nidn, nama, tanggal lahir, home base prodi, keaktifan, alamat email, dan data lain. Selain dari data identitas dari dosen, pada profil tersebut juga terdapat tab untuk mengisi riwayat penelitian dan PkM yang telah dilakukan, artikel jurnal dan prosiding yang telah diterbitkan, HKI dan buku. Selain itu juga dosen dapat merubah foto profil melalui tombol Change Photo. Gambar 7 Form data profil dosen dapat dilihat sebagaimana. 


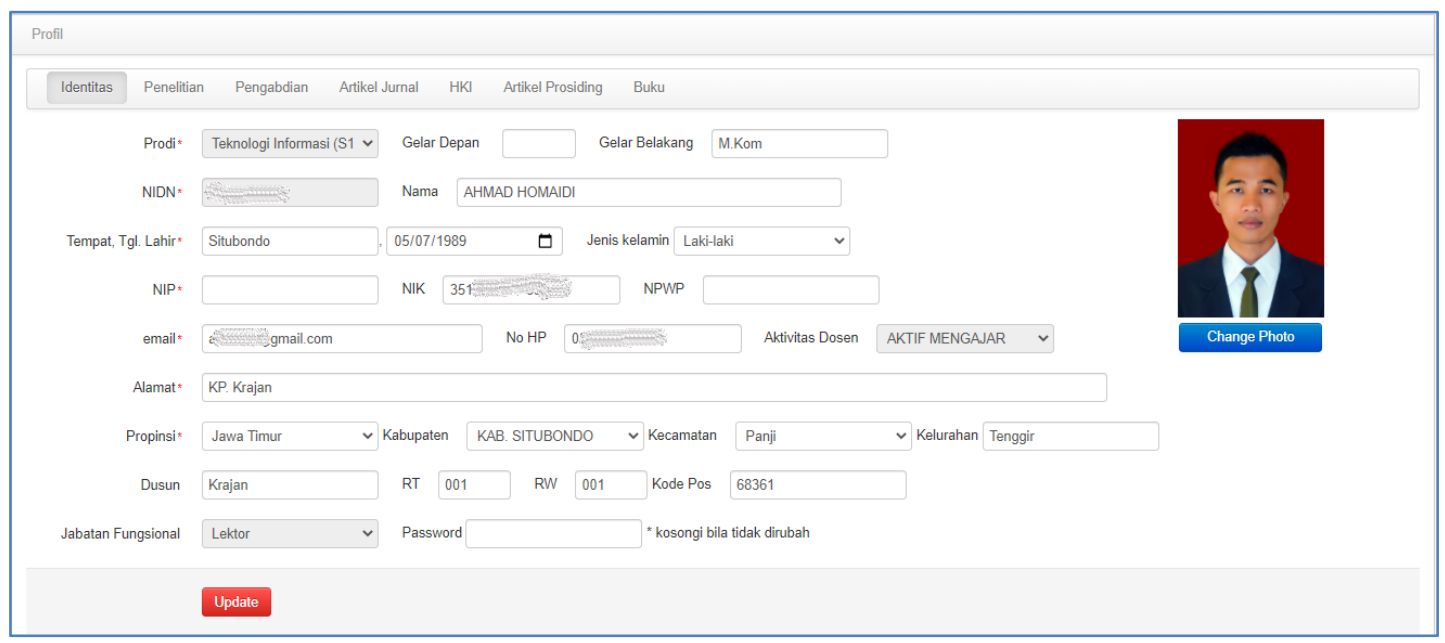

Gambar 7. Form Profil

Selanjutnya untuk mengirimkan usulan proposal dapat dilakukan sesuai menu yang disediakan, baik itu untuk penelitian maupun untuk pengabdian kepada masyarakat. Pendaftaran usulan baru dapat dilakukan dengan cara mengklik menu "Usulan Baru" yang terdapat pada menu navigasi di bagian header. Selanjutnya pengusul dapat mengisikan data usulannya sesuai dengan tahun pelaksanaan yang sudah ditentukan. Gambar 8 adalah contoh form usulan baru.

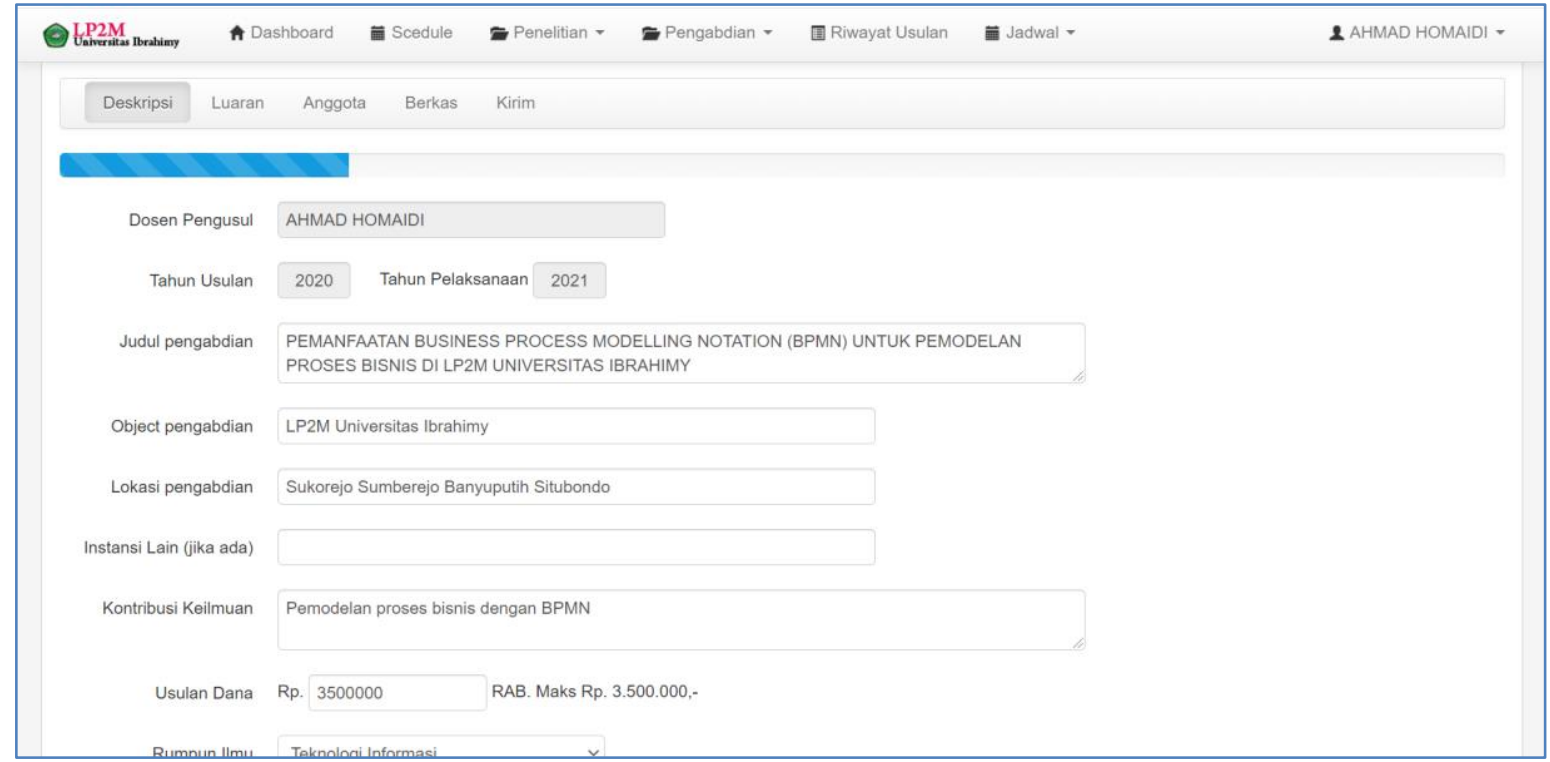

\section{Gambar 8. Form Usulan Proposal}

Pada tab pertama form usulan proposal sebagaimana gambar 8 di atas memuat deskripsi usulan, kemudian pada tab kedua memuat tentang janji luaran yang ditargetkan, tab ketiga pemilihan anggota pelaksana jika dibutuhkan, tab ke empat memuat berkas proposal yang harus diupload dan memuat lembar pengesahan yang digenerate dari aplikasi. Pada tab terakhir barulah terdapat ceklis persetujuan untuk mengirimkan proposal yang dilengkapi dengan tombol kirim.

Deskripsi yang harus diisikan dalam usulan proposal pada aplikasi ini antara lain adalah dosen pengusul, tahun usulan dan tahun pelaksanaan, judul, objek penelitian, lokasi penelitian, instansi lain (opsional), kemudian juga diharuskan menjelaskan tentang kontribusi keilmuan dari penelitian yang diajukan, usulan dana penelitian, rumpun ilmu dan terakhir bidang fokus. Kemudian pada tab luaran, pengusul diminta untuk mengisi jenis luaran yang ingin dicapai, baik berupa publikasi di jurnal, prosiding, hki, maupun buku dan jenis luaran lainnya minimal ada satu luaran yang ingin dicapai. Selanjutnya kemudian pada tab anggota, anggota pelaksana boleh tidak ada. Jika pengusul menambahkan anggota maka usulan tidak dapat mengupload berkas proposal sebelum anggota memberikan konfirmasi, baik menyetujui maupun tidak. Selanjutnya jika sudah ada konfirmasi dari calon anggota yang dipilih, maka ketua pengusul baru dapat mendownload lembar persetujuan yang selanjutnya setelah ditandatangani dapat dimasukkan ke dalam proposal, kemudian diupload pada tab berkas. Terakhir setelah semua isian wajib telah terisi maka pengusul baru dapat mencentang pernyataan persetujuan mengirimkan proposal, dan data yang dikirimkan akan masuk ke list usulan baru yang nantinya dijadikan dasar untuk dijadwalkan dalam seminar proposal oleh administrator. Gambar 9 adalah contoh lembar pengesahan yang dihasilkan dari aplikasi. 


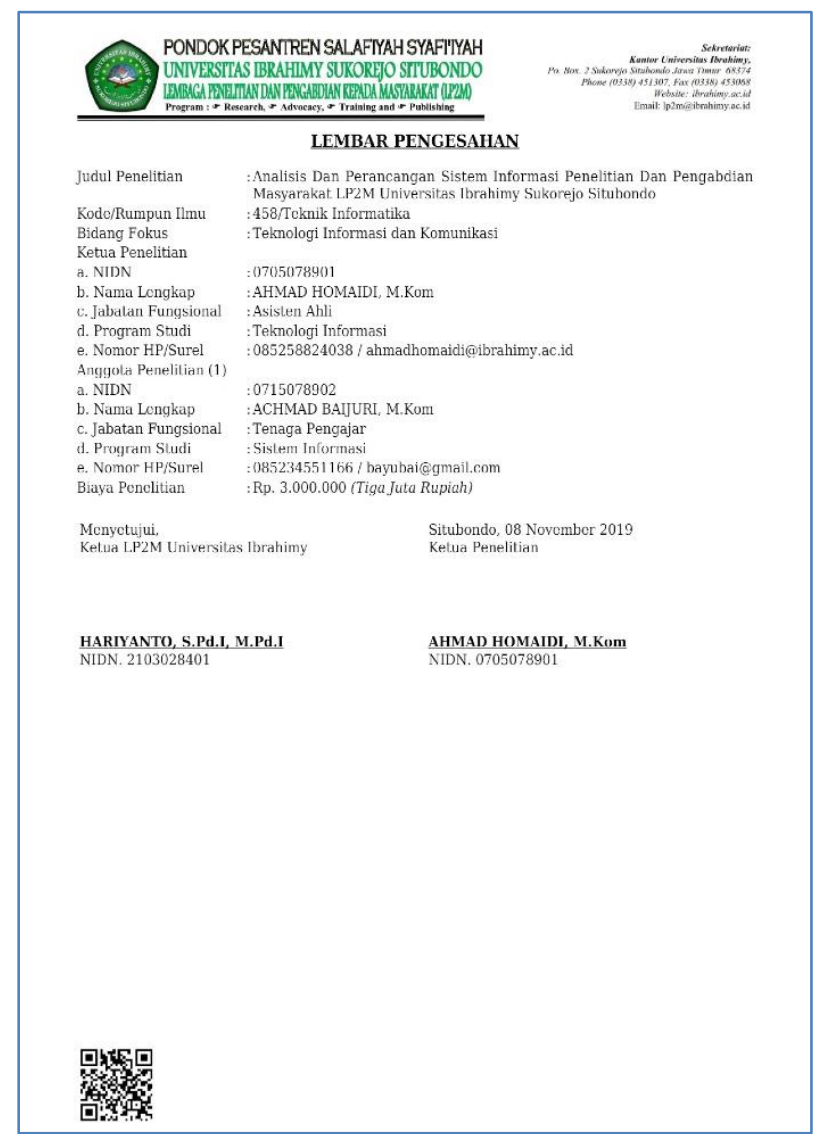

Gambar 9. Output Lembar Pengesahan

Data usulan proposal yang telah disubmit oleh dosen pengusul dapat dilihat oleh administrator melalui menu usulan baru dengan tambahan keterangan Belum Seminar. Keterangan tersebut sebagai penanda bahwa usulan tersebut belum mengikuti seminar dan belum dilakukan penilaian oleh reviewer. Gambar 10 merupakan tampilan data proposal yang telah masuk pada halaman administrator.

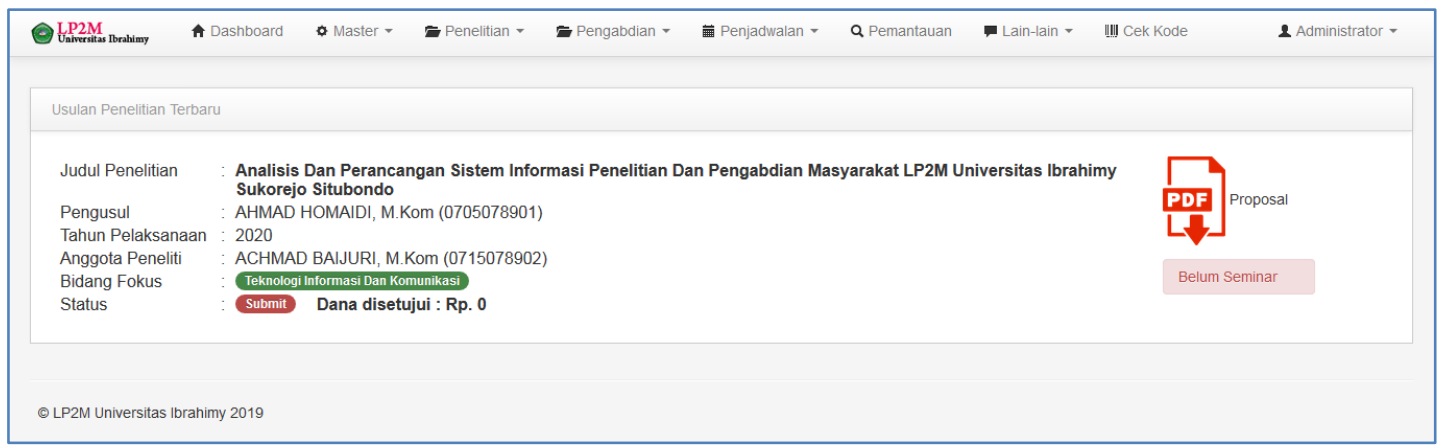

\section{Gambar 10. Data Proposal Pada Halaman Administrator}

Setelah masa pengusulan proposal baru telah selesai, pihak LP2M dapat menjadwalkan pelaksanaan seminar proposal berdasarkan data usulan yang telah masuk di aplikasi. Untuk melakukan penjadwalan dapat dilakukan dengan mengklik sub menu seminar proposal yang terdapat pada menu penjadwalan. Setelah form tampil, selanjutnya dapat digunakan untuk menentukan Ruang, Tanggal Pelaksanaan dan Waktu Pelaksanaan. Setelah itu akan ditampilkan data proposal yang diusulkan oleh para ketua pengusul, dan dilanjutkan dengan memilih reviewer yang akan ditugasi untuk memberikan penilaian terhadap proposal yang akan dijadwalkan. Setelah itu klik tombol Generate untuk menyimpan jadwal yang dibuat dan akan muncul pesan Success. Gambar 11 berikut ini merupakan tampilan dari penjadwalan yang dilakukan oleh administrator. 


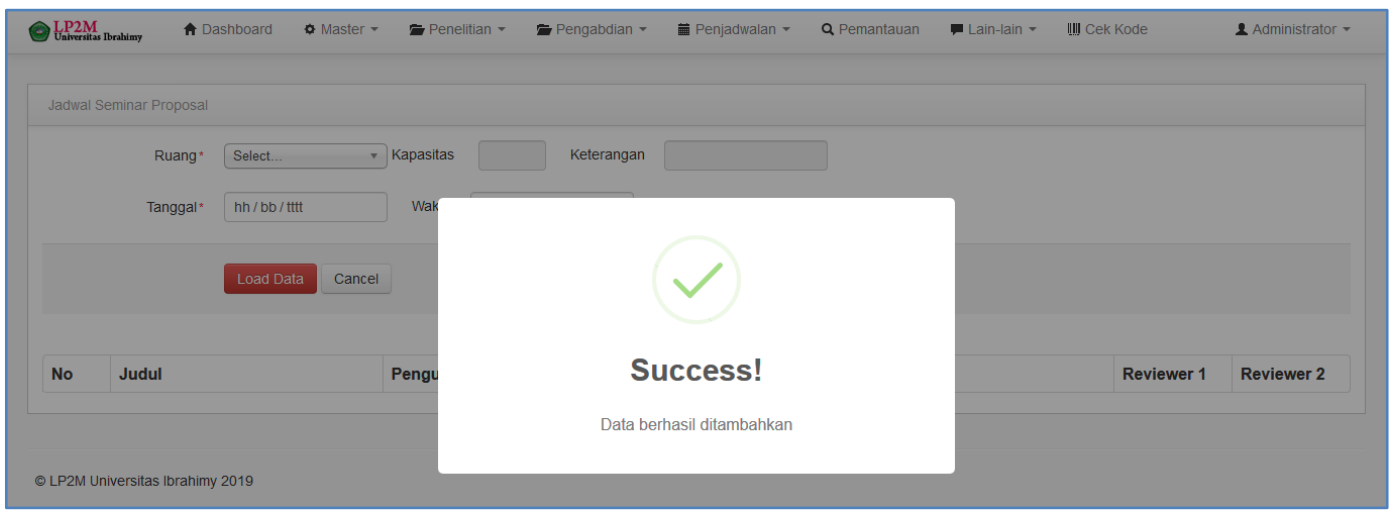

Gambar 11. Penjadwalan Seminar Proposal

Pada gambar 11 tersebut menggambar proses penjadwalan seminar yang setelah isian data telah lengkap dan mengklik tombol generate akan ditampilkan pesan sukses. Setelah itu, tampilan akan di redirect ke halaman list jadwal sebagaimana gambar 12 terdapat jadwal yang sudah di generate oleh sistem berikut tombol-tombol pelengkapnya.

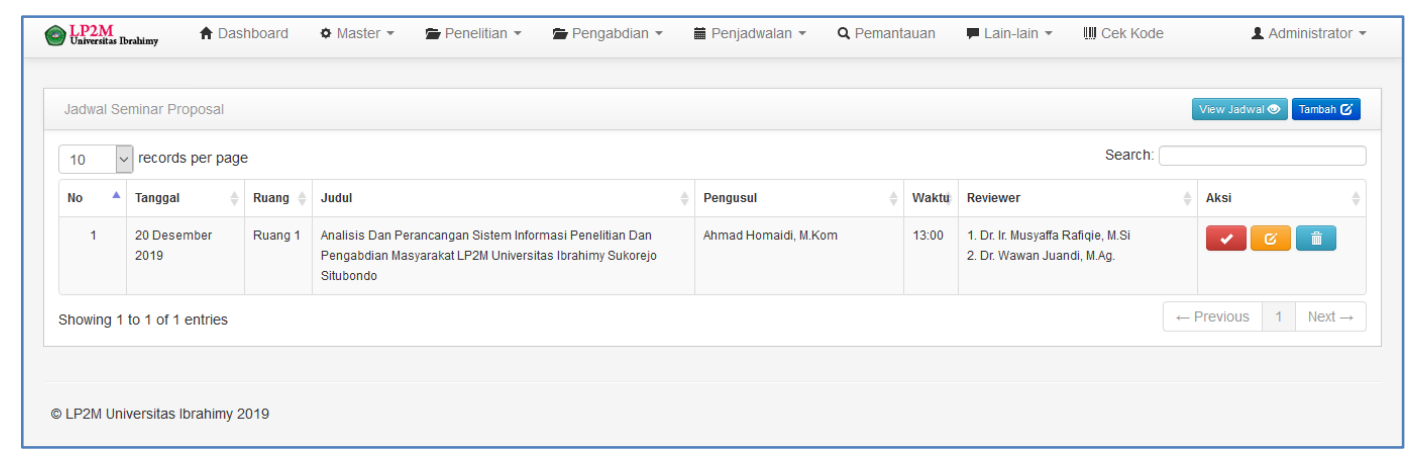

Gambar 12. List Jadwal Seminar Proposal

Pada list jadwal sebagaimana gambar 12 di atas, terdapat tombol berwarna biru langit yang digunakan untuk view jadwal. Ketika tombol tersebut diklik maka akan menampilkan ruangan beserta waktu pelaksanaan seminar yang dilengkapi dengan tombol-tombol untuk mencetak kelengkapan berkas untuk pelaksanaan Seminar proposal.

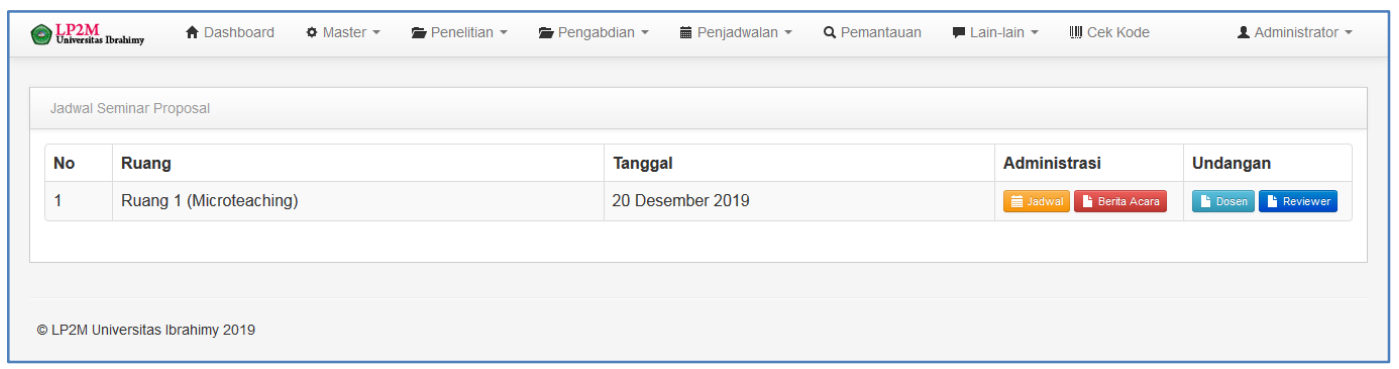

Gambar 13. View Kelengkapan Berkas Seminar Proposal

Untuk mencetak berkas pendukung pelaksanaan seminar proposal, dapat dilakukan dengan mengklik tombol yang sudah disediakan sebagaimana gambar 13 di atas. Tombol berwarna orange digunakan untuk mencetak jadwal, tombol berwarna merah digunakan untuk mencetak berita acara, tombol berwarna biru muda digunakan untuk membuat undangan kepada dosen dan tombol berwarna dongker digunakan untuk mencetak undangan kepada reviewer. Setelah pelaksanaan seminar proposal selesai dilaksanakan maka administrator dapat merubah data menjadi selesai dengan menekan tombol berwarna merah dengan icon " $\checkmark$ " pada list jadwal seminar proposal. Jika berhasil maka tombol tersebut akan berubah menjadi warna hijau. Gambar 14 merupakan tampilan setelah tombol centang diklik. 


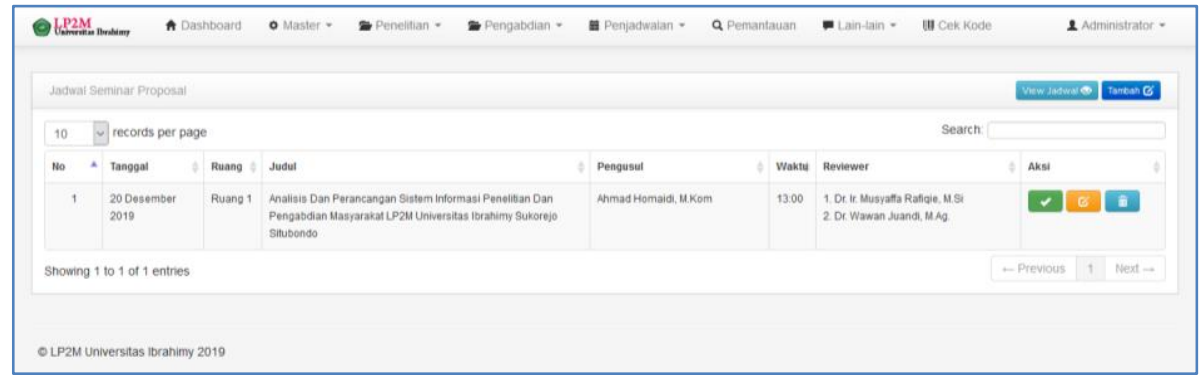

Gambar 14. View Jadwal Pelaksanaan yang Telah Selesai

Selanjutnya tampilan usulan baru akan berubah sebagaimana gambar 15 setelah sebelumnya terdapat keterangan "belum seminar”. Dengan ini menandakan bahwa seminar proposal telah selesai diikuti dosen pengusul.

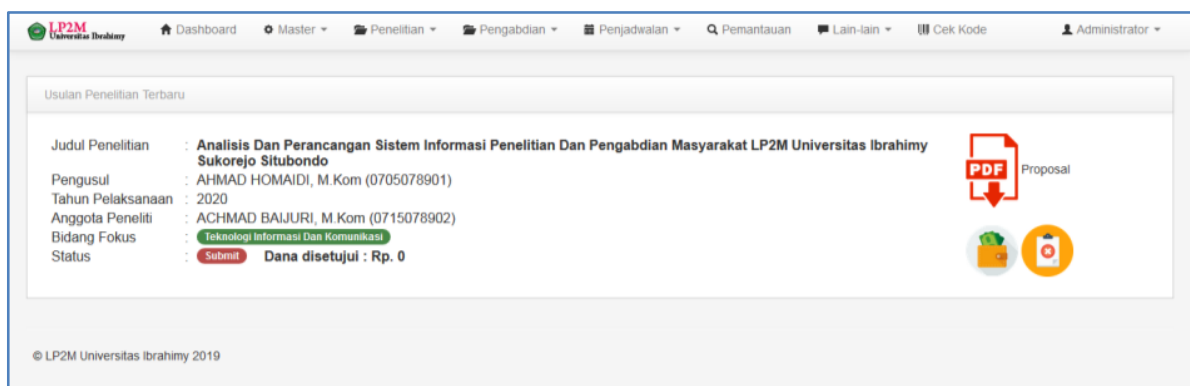

Gambar 15. Perubahan Keterangan Setelah Melakukan Seminar

Setelah keterangan belum seminar berubah, maka muncul icon yang digunakan untuk menentukan besaran dana yang akan disetujui dan icon untuk melakukan reject proposal. Jika berdasarkan hasil penilaian reviewer usulan tersebut layak untuk disetujui, maka selanjutnya klik tombol untuk menentukan besaran dana yang akan disetujui. Gambar 16 adalah tampilan form untuk menentukan besaran dana yang akan disetujui.

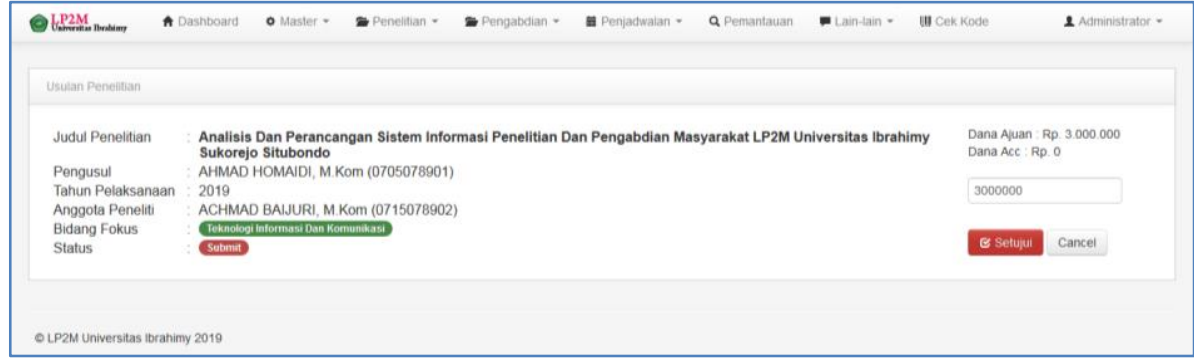

Gambar 16. Penentuan Besaran Dana

Setelah selesai menentukan besaran dana yang disetujui, klik setujui untuk menyimpan dan hasilnya akan tampil seperti gambar 17, muncul icon untuk memberikan persetujuan terhadap usulan. Setelah itu akan status usulan akan berubah menjadi "Acc".

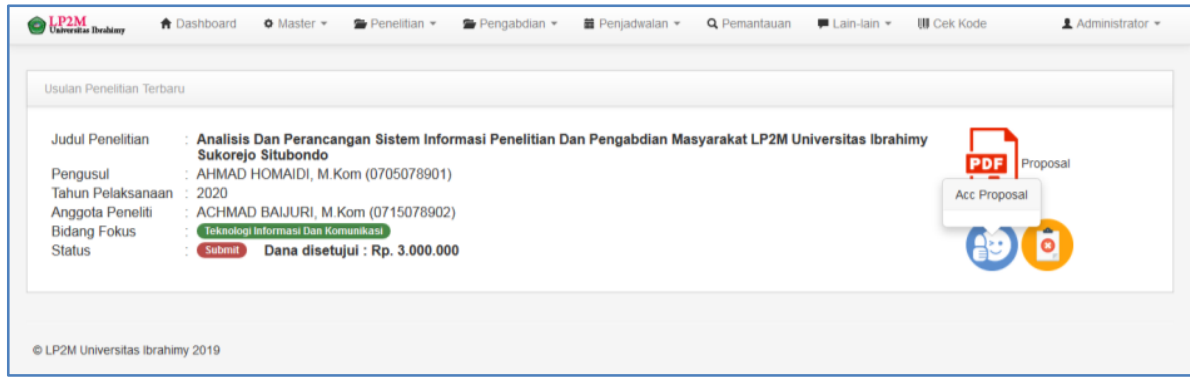

Gambar 17. Persetujuan Proposal

Sementara untuk menu pemantauan, digunakan untuk memantau progres dari usulan yang disetujui dan didanai. Pemantauan pelaksanaan meliputi catatan harian, laporan kemajuan, laporan akhir dan luaran yang dijanjikan. Untuk melakukan pemantauan terhadap progres pelaksanaan penelitian dan PkM dapat dilakukan melalui sub menu yang disediakan pada jenis usulan proposal. Namun jika untuk sekedar memastikan pelaksana telah mengisi seleuruh progres pelaksanaan yang seharusnya dilaporkan, maka 
administrator dapat melakukan pemantauan pada menu pemantauan kemudian memilihh tahun pelaksanaan dan klik tomobol search. Selanjutnya list data pengusul beserta judulnya akan ditampil, berikut ceklist progres pelaksanaan yang meliputi catatan haria, laporan kemajuan, laporan akhir dan luaran hasil. Ceklist data dengan tanda silang (x) menandakan bahwa belum ada data yang dimasukkan atau tidak dilaksanakan oleh pengusul, sebaliknya jika ceklist sudah berbentuk cawang $(\checkmark)$ menandakan bahwa sudah terdapat data pada progres pelaksanaan kegiatan. Gambar 18 adalah tampilan list pemantauan pelaksanaan.

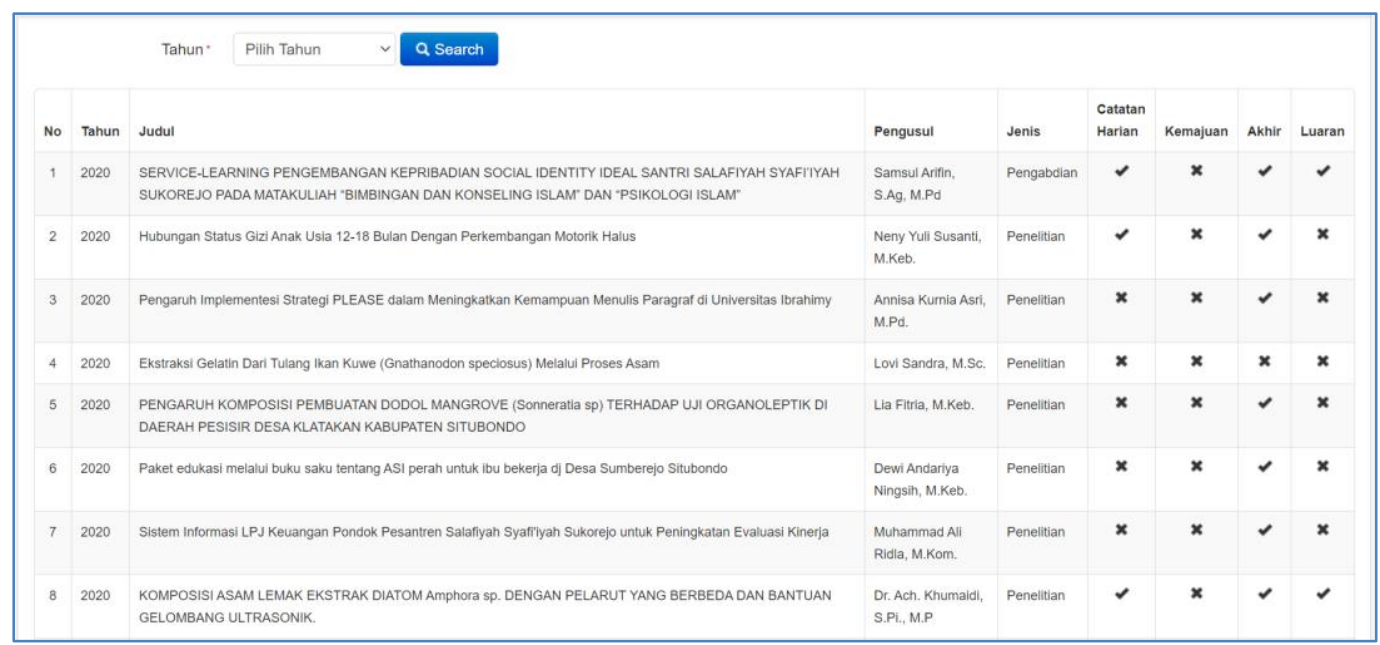

Gambar 18. List Pemantauan Pelaksanaan Penelitian dan PkM

Dengan pemantauan ini diharapkan dapat memudahkan pihak LP2M untuk memantau perkembangan pelaksanaan penelitian dan PkM dosen.

\subsection{Testing}

Pengujian dilakukan untuk memastikan bahwa aplikasi yang dibangun sudah terhindar dari kesalahan-kesalahan dalam pemrograman atau ketidak sesuaian dengan harapan pengguna. Oleh karena itu pengujian pada aplikasi ini sangat perlu dilakukan, untuk menjaga kualitas dari aplikasi serta untuk menjamin aplikasi dapat digunakan secara berkesinambungan. Pengujian pada aplikasi ini menggunakan Web Quality Evaluation Method [15] yang di dalamnya dilakukan pengujian terhadap functionally, reliability, usability, dan efficiency.[16] Pengujian dilakukan oleh 10 orang pengguna yang diberikan hak untuk mengakses fitur dari website, kemudian diminta untuk menjawab 18 pertanyaan dengan interval penilaian 1 sampai 5 dan pertanyaan tersebut telah mewakili masing-masing item dari metode pengujian yang dilakukan. Rumus yang digunakan dalam pengujian ini adalah sebagai berikut;

$$
\text { Prosentase }=\frac{\sum \text { nilai }}{\text { Nilai Maximum }} \times 100 \%
$$

Berdasarkan hasil pengujian yang dilakukan pada pelaksanaan penerimaan proposal penelitian dan pengabdian masyarakat pada tahun sebelumnya, aplikasi ini memperoleh prosentase penilaian sebesar $90 \%$ dari penilaian pengguna, yaitu pihak-pihak yang terlibat langsung dengan aplikasi yang dibuat. Sebagaimana digambarkan dalam rekapitulasi hasil pengujian pada table 1 berikut.

Tabel 1. Hasil Pengujian

\begin{tabular}{lcccc}
\hline \multirow{2}{*}{ Aspek } & \multicolumn{3}{c}{ Skor } & \multirow{2}{*}{ Kriteria } \\
\cline { 2 - 4 } & Aktual & Ideal & $\mathbf{\%}$ & \\
\hline Functionally & 186 & 200 & 93 & Sangat Baik \\
Reliability & 267 & 300 & 89 & Baik \\
Usability & 220 & 250 & 88 & Baik \\
Efficiency & 140 & 150 & 93 & Sangat Baik \\
\hline Total & $\mathbf{8 1 3}$ & $\mathbf{9 0 0}$ & $\mathbf{9 0}$ & Sangat Baik \\
\hline
\end{tabular}

Hal ini menandakan bahwa aplikasi ini sudah sangat baik dan dapat menjadi alternatif solusi dari permasalahan yang selama ini terjadi dan dapat menjadi gudang digital untuk data penelitian dan pengabdian masyarakat berikut luaran yang dihasilkan. Sehingga proses pelaksanaan sampai pelaporan penelitian dan pengabdian masyarakat di Universitas Ibrahimy menjadi lebih efektif dan efisien, serta terdokumentasi dengan baik, dan jika sewaktu-waktu data tersebut dibutuhkan dapat dengan mudah didapatkan melalui website yang disediakan. 


\section{KESIMPULAN}

Aplikasi yang dibangun dalam penelitian ini dapat menghandle proses pengusulan proposal penelitian dan pengabdian kepada masyarakat di internal Universitas Ibrahimy, meliputi proses pengusulan proposal, penjadwalan seminar, pencatatan progres pelaksanaan meliputi catatan harian, laporan kemajuan, laporan akhir, dan luaran hasil. Dengan adanya aplikasi ini pihak LP2M Universitas Ibrahimy dapat dengan mudah mengorganisir penelitian dan pengabdian kepada masyarakat, karena seluruh data dapat terdata dengan baik dan segala berkas yang dibutuhkan dapat dicetak dari aplikasi. Selain itu juga memudahkan kepada dosen dalam mengusulkan proposal penelitian dan pengabdian kepada masyarakat, tanpa harus menyerahkan hardcopy, begitu juga dengan reviewer yang cukup mengganti perannya saja sebagai reviewer dan dapat mendownload proposal yang didistribusikan untuk dinilai. Berdasarkan hasil pengamatan peneliti, diperlukan perbaikan standar operasional prosedur dalam beberapa proses bisnis yang dilakukan, yaitu kedepannya sebaiknya seluruh proses bisnis dapat dilakukan menggunakan aplikasi yang online, sehingga dapat menjadi lebih efektif dan efisien.

\section{REFERENSI}

[1] H. Hamzah, "Sistem Informasi Kegiatan Penelitian dan Pengabdian Kepada Masyarakat Universitas Respati Yogyakarta," Jurnal Nasional Teknologi dan Sistem Informasi, vol. 2, no. 2, pp. 17-26, 2016.

[2] I. C. Mauko, N. M. Setiohardjo, and F. P. Noach, "Pengembangan website unit penelitian dan open source di Politeknik Negeri Kupang," Jurnal Ilmiah FLASH, 2017.

[3] M. Dewi, “Analisis Statistik Keterpakaian Database Online Science Direct (Januari - Juni 2018) dalam Mengambil Kebijakan Pengadaan Bahan Pustaka Elektronik pada Perpustakaan Universitas Islam Indonesia," Al-Kuttab: Jurnal Kajian Perpustakaan, Informasi dan Kearsipan, vol. 1, no. 1, pp. 23-34, 2019.

[4] T. Andrasto, "Pengembangan Sistem Database Hasil Penelitian dan Pengabdian kepada Masyarakat Dosen UNNES," Emitor - Jurnal Teknik Elektro, vol. 5, no. 2, pp. 64-68, 2013.

[5] G. B. Putra, "Rancang Bangun Sistem Penelitian dan Pengabdian Masyarakat Universitas Bangka Belitung Berbasis Web Server," Jurnal Ecotipe :Electronic, Control, Telecommunication, Information, and Power Engineering, vol. 4, no. 1, pp. 17-22, Apr. 2017.

[6] S. Dalis, "Rancang Bangun Sistem Informasi Lembaga Penelitian dan Pengabdian Masyarakat Berbasis Web," Paradigma - Jurnal Komputer dan Informatika, vol. 19, no. 1, pp. 1-8, Apr. 2017.

[7] A. Dennis, H. B. Wixom, and D. Tegarden, Systems Analysis Design with UML Version 2.5: An Object-Oriented Approach. 2015.

[8] M. P. Putri and B. Bobby, "Sistem Informasi Manajemen Proyek PT. Samudera Perkasa Konstruksi Berbasis Web," MATRIK: Jurnal Manajemen, Teknik Informatika dan Rekayasa Komputer, vol. 20, no. 1, pp. 85-96, Sep. 2020.

[9] A. Homaidi and A. Lina, "Pengembangan Sistem Informasi Manajemen Berbasis Web dalam Rangka Mendukung Evaluasi Kinerja Akademik dan Dosen di Akademi Manajemen Informatika dan Komputer Ibrahimy," Applied Technology and Computing Science Journal, vol. 2, no. 1, pp. 25-38, Sep. 2019.

[10] R. S. Pressman, Software Engineering: a Practitioner's Approach, 8th Edition, 8th ed. New York, 2015.

[11] I. Yunita and M. A. Ridla, "Perancangan dan Implementasi Sistem Informasi Pelayanan Jam'iyah Umroh Hafas," Jurnal Ilmiah Informatika, vol. 4, no. 2, pp. 53-62, Dec. 2019.

[12] A. Homaidi and R. Munawaroh, "Rekonstruksi dan Implementasi Sistem Informasi Praktek Kerja Lapangan AMIK Ibrahimy," MATRIK : Jurnal Manajemen, Teknik Informatika dan Rekayasa Komputer, vol. 18, no. 2, pp. 180-191, May 2019.

[13] A. Nugroho, N. Wakhidah, and B. V. Christioko, "Sistem Informasi Secara Online Tugas Akhir Mahasiswa Jurusan Teknologi Informasi Fakultas Teknologi Informasi dan Komunikasi," Jurnal Transformatika, vol. 13, no. 1, pp. 13-19, 2015.

[14] A. Homaidi and S. Ibad, "Analisis Pemodelan Sistem Pengaduan Kasus Menggunakan Object Oriented Method (Unified Modelling Language)," Jurnal Ilmiah Informatika, vol. 4, no. 1, pp. 47-52, Jun. 2019.

[15] T. N. Sari, “Analisis Kualitas Dan Pengembangan Sistem Informasi Akademik Berbasis Web Menggunakan Standard ISO 9126," JIKO: Jurnal Informatika dan Komputer, vol. 1, no. 1, pp. 1-7, 2017.

[16] A. Ghofur and Muhasshanah, "Perancangan dan Implementasi Sistem Informasi Target Pertolongan Persalinan Mahasiswa Kebidanan Universitas Ibrahimy dalam Praktik Klinik Kebidanan," NJCA Nusantara Journal of Computers and Its Applications, vol. 3, no. 2, pp. $1-12,2018$. 
Matrik : Jurnal Manajemen, Teknik Informatika, dan Rekayasa Komputer,

Vol. 20, No. 2, Mei 2021: 225 236 